\title{
Identifying Areas Sensitive to Wind Erosion-A Case Study of the AP Vojvodina (Serbia)
}

\author{
Aleksandar Baumgertel * ${ }^{*}$, Sara Lukić ${ }^{\circledR}$, Snežana Belanović Simić ${ }^{\circledR}$ and Ratko Kadović \\ Department of Ecological Engineering for Soil and Water Resources Protection, University of Belgrade Faculty of \\ Forestry, Belgrade 11000, Serbia; sara.lukic@sfb.bg.ac.rs (S.L.); snezana.belanovic@sfb.bg.ac.rs (S.B.S.); \\ ratko.kadovic@sfb.bg.ac.rs (R.K.) \\ * Correspondence: aleksandar.baumgertel@sfb.bg.ac.rs
}

Received: 23 September 2019; Accepted: 30 October 2019; Published: 26 November 2019

\begin{abstract}
Wind erosion is one of the most significant forms of land degradation which occurs in arid and semi-arid regions. Agricultural land is significantly affected by wind erosion, which leads to soil quality reduction, and consequently to economic losses. This research was conducted in the autonomous province (AP) of Vojvodina (a region dominated by agriculture), which represents one of the most important economic regions in the Republic of Serbia. The aim of this research was to identify areas sensitive to wind erosion (in the month of March) in the AP Vojvodina by using fuzzy logic, remote sensing data, and geographical information systems (GIS). The data of prior research on erosion sediment were used for results validation. The results show that the hazardous sensitivity category covers approximately $60.41 \%$ of the research area, while the medium sensitive category accounts for $36 \%$ of the area. These findings are primarily a result of the lack of vegetation in almost the entire area, particularly in wind-exposed agricultural areas with no vegetation, which are being prepared for sowing. Another factor putting such a large area at risk is the unfavorable climate (especially in southeastern parts of the area), and slightly less favorable soil properties in the north. The results of this research could be used in decision-making at the regional level, along with the development and implementation of programs aimed at mitigating the effects of wind erosion.
\end{abstract}

Keywords: wind erosion; fuzzy logic; spatial modeling; GIS; Republic of Serbia (AP Vojvodina)

\section{Introduction}

Wind erosion is one of the most significant forms of land degradation [1] in arid and semi-arid areas. Agricultural land is particularly affected by the loss of fine soil particles and organic matter [2], resulting in economic losses [3] and reduced soil quality [4]. It is estimated that $28 \%$ of the world's soils, including $1.3 \mathrm{mil} \mathrm{km}{ }^{2}$ of European agricultural soils, are affected by wind erosion processes [5].

In the Republic of Serbia, soils of the autonomous province (AP) Vojvodina are the most susceptible to wind erosion, due to the physical and geographical characteristics of the area (flat relief, lack of forest vegetation, intensive agriculture, and wind regime) (Figure 1). The research area was located in the Panonian Plain, where soils are characterized as very good for agriculture [6]. The AP Vojvodina is one of the most important economic regions in the Republic of Serbia, with a $61.5 \%$ to $88.3 \%$ share of production of the main agricultural crops (maize, sugar beet, soybeans, and sunflowers) [7]. An increase in the forest cover from $6.37 \%$ to the optimum of $14.32 \%$, in line with the European standards, is one of the goals of the document Optimum Afforestation in Vojvodina, drafted by the public enterprise for forest management "Vojvodina Forests" [8]. In terms of agribusiness, the region AP Vojvodina has all the prerequisites (fertile soil, optimal climate conditions, organic production potentials) to successfully supply the fast-growing global markets with premium food products [9]. 


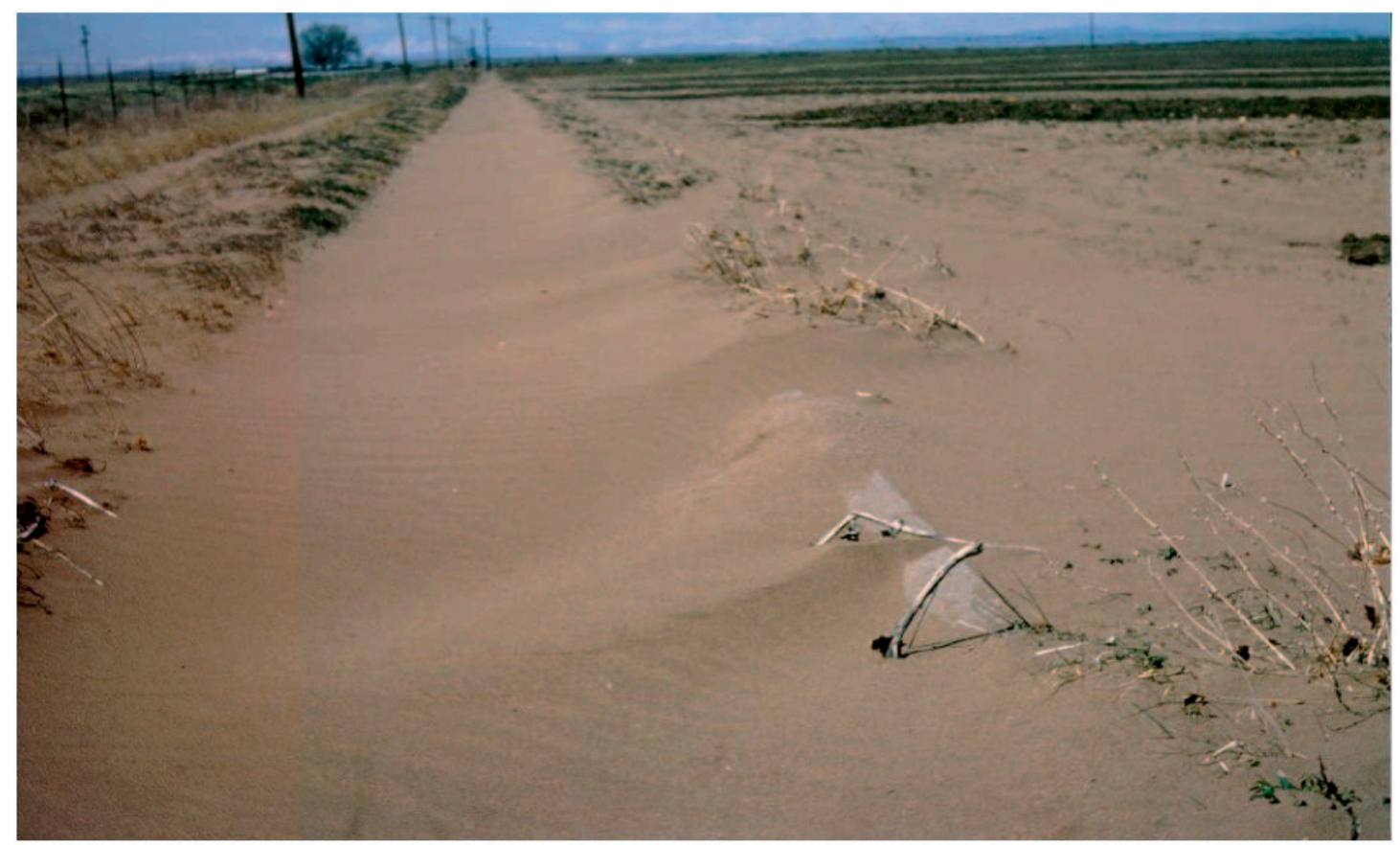

Figure 1. Wind erosion in the autonomous province (AP) Vojvodina (photo by Letić, 2009).

In the last century, important investigations relating to wind erosion were performed at certain locations in the AP Vojvodina [10,11]. Almost 20 years later, Savić [12] investigated the vulnerability of the AP Vojvodina to wind erosion. In a recent study, Veloić [13] quantified the eolian process in the Deliblato sands. The abovementioned researchers mainly conducted their investigations at a small scale (Horgoš and Deliblato sands). In the case of the researcher Savić [10], the whole area of the AP Vojvodina was included. However, that research focused only on the climate factor as one of the indicators of wind erosion vulnerability.

Numerous models have been developed for the assessment of wind erosion sensitivity. In the late 1950s, the empirical physical model Wind Erosion Equation (WEQ) was developed [14], followed by an improved version, Revised Wind Erosion Equatio(RWEQ) [15]. Many other models have also been developed. By developing new methods of spatial data analysis and by collecting data using remote sensing, the abovementioned models are integrated and implemented in the geographical information system (GIS) surroundings [16,17]. More recently, models which use input data based on both empirical and theoretical knowledge have been widely applied to identify wind erosion vulnerability zones [18,19].

So far, a large-scale assessment of wind erosion in the Republic of Serbia has not been carried out. The aim of this research is to identify areas sensitive to wind erosion in the AP Vojvodina by using fuzzy logic, remote sensing data, and geographical information systems (GIS). The data of prior research on the erosion sediment $[13,20]$ were used for results validation. This research used a model based on fuzzy logic, which is increasingly used in environmental studies. The results of this research should highlight the hotspots which are most at risk. This risk is a result of both natural characteristics and the type of land use in the area (agricultural use). Furthermore, those results can be used for decision-making and the development/implementation of programs aimed at mitigating the effects of wind erosion at the regional level in the AP Vojvodina. 


\section{Materials and Methods}

\subsection{Research Area}

The AP Vojvodina represents one of the most important socio-economic regions in the Republic of Serbia. The AP Vojvodina is positioned in the northern part of the Republic of Serbia on an area of $21,506 \mathrm{~km}^{2}$ (Figure 2). The entire area of AP Vojvodina is located in the Pannonian Plain (with the exception of the North Mačva region) and the relief is flat (with the exception of Srem and south-eastern Bačka). The area of AP Vojvodina is characterized by a moderate continental climate [21]. During the 1997-2017 period the mean annual temperature was $12.1^{\circ} \mathrm{C}$, while the mean annual precipitation amounted to $649.35 \mathrm{~mm}$. According to Wind Atlas Balkan (WAB) [22], during the 1979-2010 period, the mean annual wind velocity in the windiest southeastern area of the AP Vojvodina was $7 \mathrm{~m} \mathrm{~s}^{-1}$. In the western part of the AP Vojvodina, the mean annual wind velocity was below $5 \mathrm{~m} \mathrm{~s}^{-1}$. Mean wind velocity varies month after month, and the highest wind velocities and numbers of days with a wind speed of above $12.6 \mathrm{~m} \mathrm{~s}^{-1}$ were recorded in March and April (RHMOS 1997-2017) [23]. Due to natural conditions (climate, wind speed, flat area, and intensive agriculture on wide fields with insufficient woody vegetation), the risk of wind erosion processes is quite high. The occurrence of strong and dry winds coincides with an insufficient vegetation cover and excessive pruning of the surface soil layer (on agricultural land), especially in March and April.

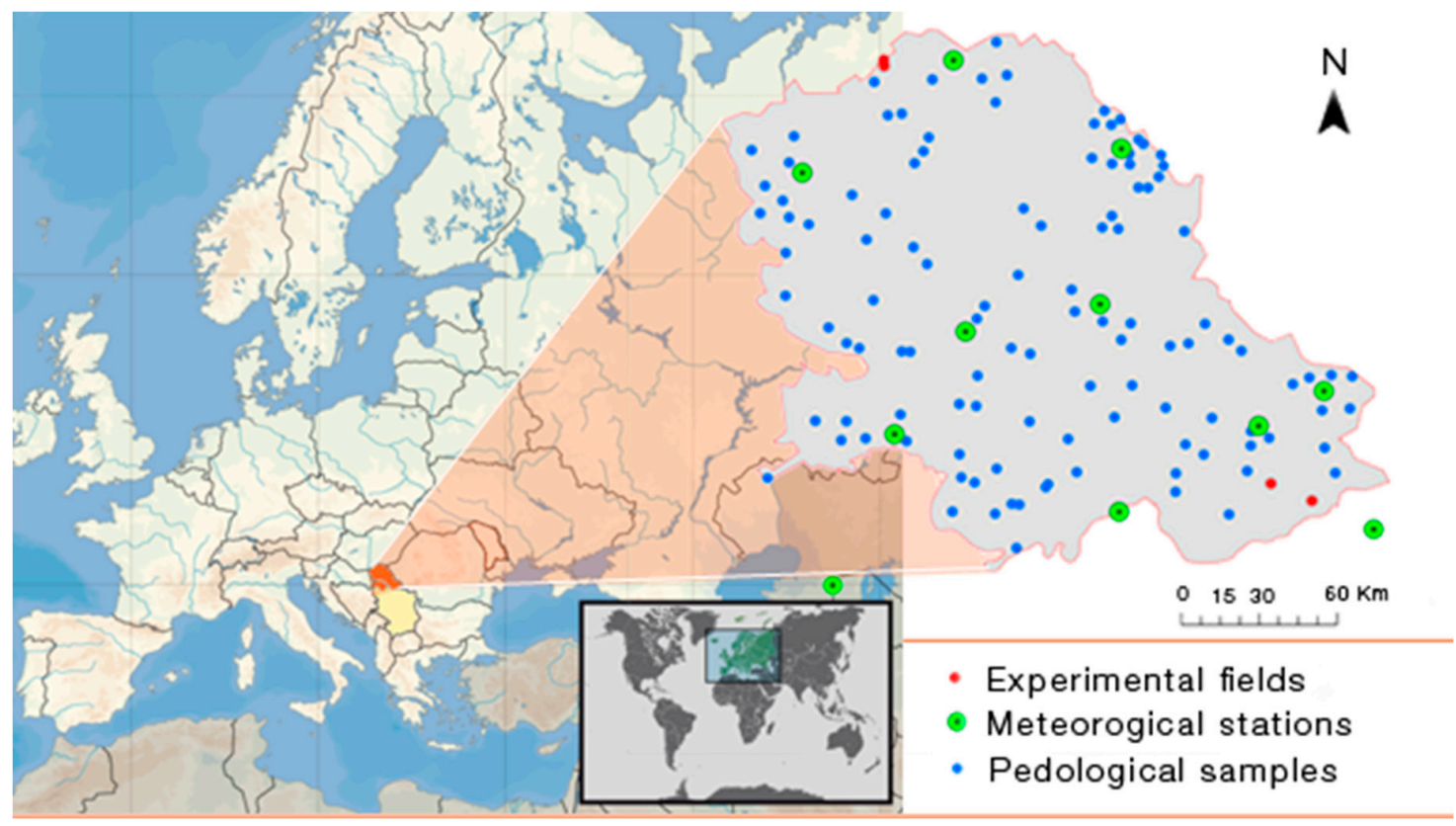

Figure 2. A map of the research area in the AP Vojvodina (showing soil samples, meteorological stations and sample plots).

\subsection{Data}

The main factors used for modeling the vulnerability to wind erosion processes were climate characteristics (wind speed, temperature, and precipitation), the presence of vegetation, and soil properties. The following datasets were used in this research:

- $\quad$ Soil: soil texture (sand, silt, and clay content), the organic matter content and the $\mathrm{CaCO}_{3}$ content. The soil data were obtained from a soil study of the AP Vojvodina soils [24];

- Climate: wind velocity, air temperature, and precipitation. The climate data (average monthly temperature, average monthly precipitation, and average monthly number of days with a wind velocity of above $12.4 \mathrm{~m} \mathrm{~s}^{-1}$ ) were obtained from the annuals (1997-2007) for the month of March from the Republic Hydrometeorological Service of Serbia (RHMOS) [23]; 
- Vegetation: vegetation cover. The data concerning the vegetation cover were obtained from the Copernicus Global Land Service (CGLS) [25], a ready-made product of 10-daily difference vegetation index (NDVI) index images (resolution $300 \times 300 \mathrm{~m}$ ) for the area of the AP Vojvodina, for March 2016-2019. The data are available at https://land.copernicus.eu/global/products/ndvi and they were accessed on 11 April 2019;

- Land use data: the data on land use were used without the areas which were not considered in this research as irrelevant for wind erosion processes, such as urban areas, water bodies, and mining areas. In order to exclude the abovementioned areas, CORINE Land Cover 2018 was used [26]. The data are available at https:/land.copernicus.eu/pan-european/corine-land-cover/ clc2018?tab=download and they were accessed on 10 May 2019.

\subsubsection{Erodibility Fraction Analysis}

In prior research, a combination of soil sieving and wind tunnel experiments provided evidence for the relationship between soil erosion by wind and soil surface properties [27]. According to Chepil [27], aggregates larger than $0.84 \mathrm{~mm}$ in diameter were less erodible. The erodibility fraction of European soils was calculated in the research Borrelli et al. [28]. In another study $[29,30]$ they combined the erodibility fraction with other factors (climate, vegetation cover) in order to obtain the sensitivity of European agricultural soils to wind erosion. In order to calculate the erodibility fraction, this research used a multiple regression equation based on soil texture [31]:

$$
E F=\frac{29.09+0.31 S a+0.17 S i+0.33 \mathrm{Sc}+2.59 \mathrm{OM}-0.95 \mathrm{CaCO}_{3}}{100}
$$

where $S_{a}$ is sand content, $S_{i}$ is silt content, $S_{c}$ is the ratio of sand and clay, OM is organic matter content, and $\mathrm{CaCO}_{3}$ is calcium carbonate content.

\subsubsection{Climate Factor Analysis}

Sensitivity to wind erosion is affected by climatic conditions. Mean wind velocity reached a maximum in March and April. There were 11 days with a wind speed of over $12 \mathrm{~ms}^{-1}$ in March and 10 such days in April. Therefore, March and April can be considered the most important months in predicting wind erosion sensitivity. In prior research, wind velocity was considered the main trigger of wind erosion processes [18,19]. Saadoud et al. [32] and Mezösi et al. [33] further investigated air temperature and precipitation. In a particular area of AP Vojvodina (Deliblato sands), Kadović et al. [34] pointed to the drought factor in relation to the soil degradation caused by desertification processes. In a study carried out in AP Vojvodina, Savić et al. [35] investigated the climate factor using the de Martonne aridity index [36], along with wind velocity data. The climate factor applied in this research was calculated as:

$$
C F=\frac{\mathrm{v} 2 * \mathrm{~N}}{\mathrm{Is}}
$$

where $\mathrm{v}$ is the mean monthly wind velocity $(\mathrm{m} / \mathrm{s}), \mathrm{N}$ is the number of days per month with wind velocity above $12.4 \mathrm{~m} \mathrm{~s}^{-1}$, and Is is the de Martonne aridity index.

\subsubsection{Vegetation Cover Analysis}

The presence of vegetation has an important role in reducing wind erosion [37]. The vegetation cover for the month with the most severe wind erosion (March) was calculated based on remote sensing data. The data for the vegetation cover were obtained using the normalized difference vegetation index (NDVI), calculated as:

$$
N D V I=\frac{(\mathrm{NIR}-\mathrm{R})}{(\mathrm{NIR}+\mathrm{R})}
$$

where $\mathrm{R}$ is the red spectral reflectance and NIR is the near infrared spectral reflectance. 


\subsection{Methodology}

The sensitive-indicator approach was used in this research [19] (sensitivity for wind erosion is correlated with the content of erodible fraction, vegetation cover, and climate factor). First, maps of the abovementioned factor were obtained (using interpolation methods, such as kriging, and Inverse Distance Weighting (IDW). Furthermore, the sensitivity to wind erosion for each factor (soil erodibility, climate factor, and vegetation cover) was first calculated separately using fuzzy logic $[18,19,29]$, which was developed by Zadeh [38]. The relationship between the two variables (the first variable was one of the above mentioned factors and the second one was sensitivity to wind erosion) could be described by fuzzy membership functions (Figure 3), where each unit is assigned values between 0 and 1 . No possibility of wind erosion was assigned 0 , while 1 indicates maximum sensitivity. The relationship between the erodibility fraction and the rate of wind erosion was represented by a linear fuzzy membership function (Figure 3c) [29]. The same function was applied to the relationship between the climate factor and the rate of wind erosion (Figure 3b) [33]. The relationship between the vegetation cover and the rate of wind erosion was represented by a J-shaped monotonically decreased fuzzy membership function (Figure 3a) [19].
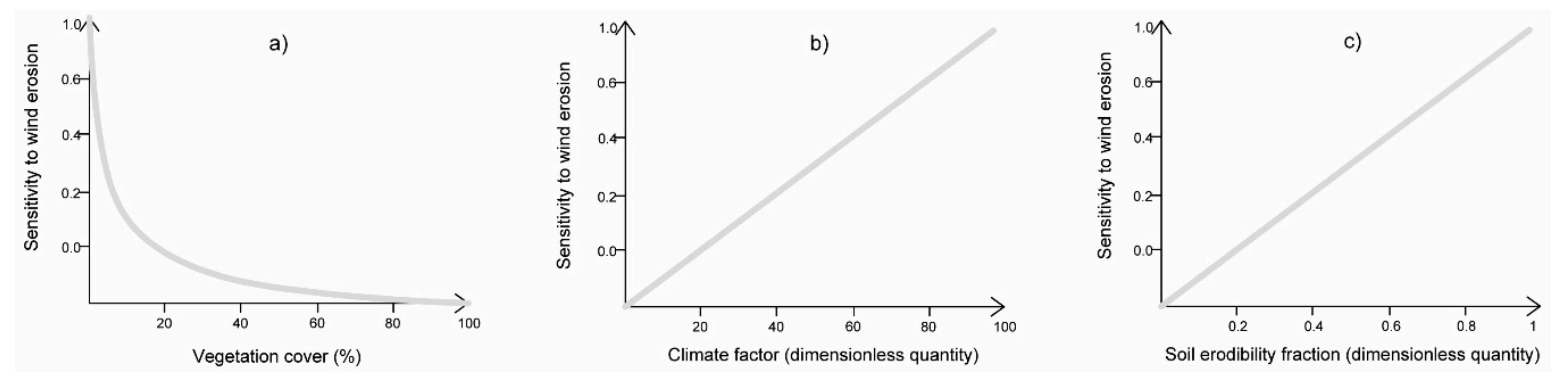

Figure 3. Applied fuzzy membership functions for each affecting factor (a) vegetation cover; (b) climate factor; (c) soil erodibility fraction.

By using the above-described relationship (between the rate of wind erosion and the contributing factors), sensitivity maps were produced for each factor, which showed the spatial distribution of sensitivity for each factor in wind erosion. The individual factor maps were overlapped and an integrated map with zones vulnerable to wind erosion was obtained. In addition, the sensitivity map excluded urban areas, objects such as mine areas, airports, and water bodies. The fuzzy analysis and spatial analysis were carried out by IDRISI Taiga software (Clark Labs, Worcester, MA) and ArcMap 10.3 (ESRI, Redlands, CA). A full overview of the methodological framework is given in the scheme below (Figure 4). 


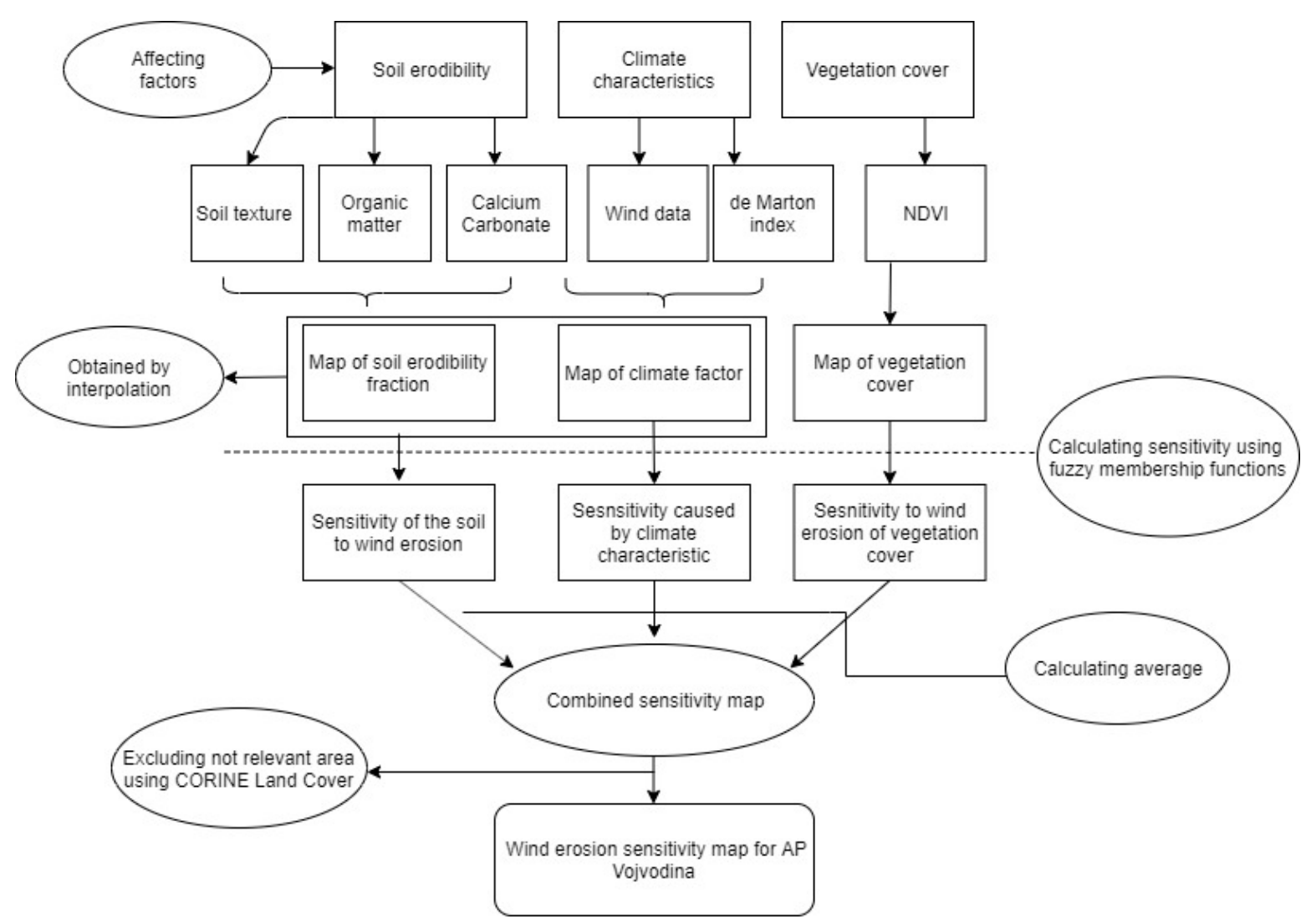

Figure 4. An overview of the applied methodological framework.

\section{Results and Discussion}

Sensitivity maps for each factor were produced by using the above-described relationship between the rate of wind erosion and the contributing factors (Figures 5-7). These maps showed the spatial distribution of sensitivity of the individual factors contributing to wind erosion. After that, a synthesis map of the vulnerability of the entire research area to wind erosion was obtained (Figure 8).

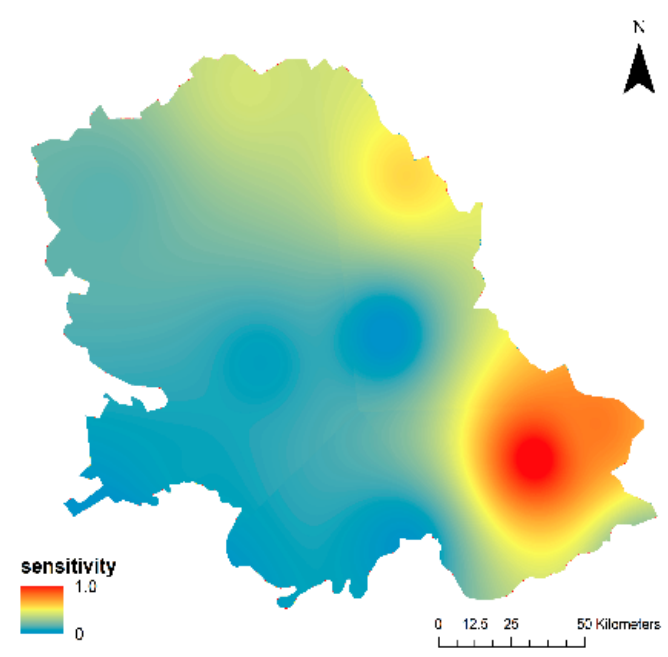

Figure 5. Sensitivity of the climate factor. 


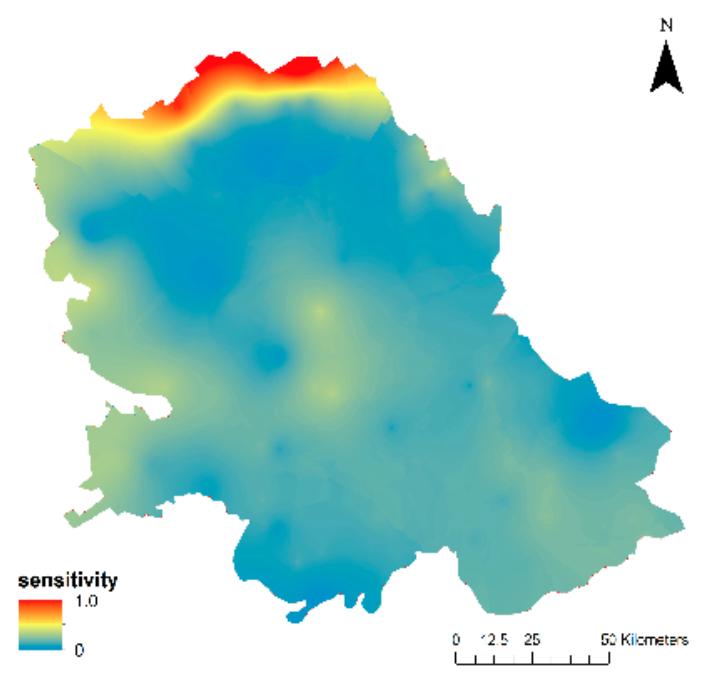

Figure 6. Sensitivity of the soil.

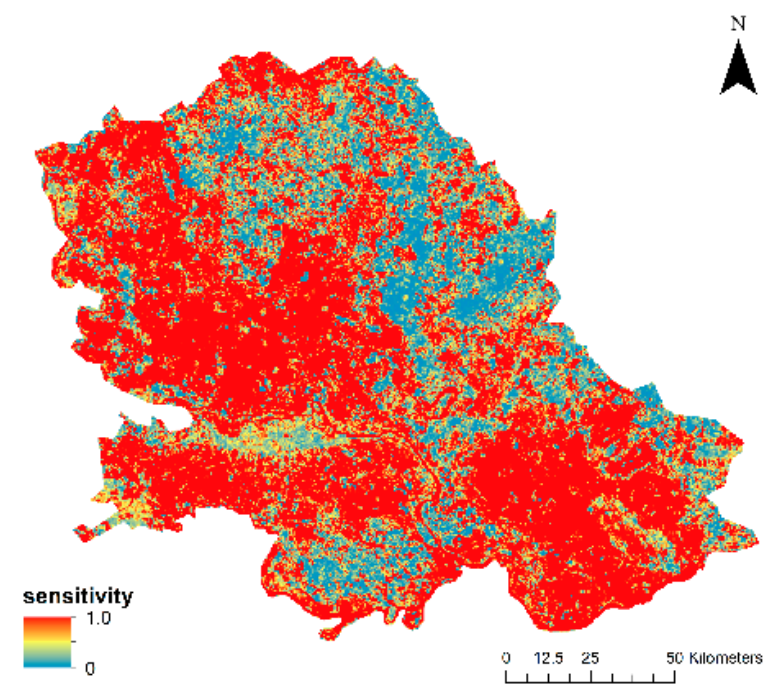

Figure 7. Sensitivity of the vegetation cover.

The map of soil sensitivity (Figure 6) to wind erosion clearly shows a generally low erodibility for the whole research area. Low soil vulnerability (high resistance) to wind erosion processes depends on the soil structure (fine silty loam and sandy loam) being mainly composed of chernozems [39]. This soil was characterized by a high content of organic matter and a favorable structure [40]. Slightly higher erodibility occurs in the far north, as a result of anthropogenic impact on soils with a lower content of organic matter [41]. The vegetation cover is a key factor for protecting the soil from wind erosion [42]. The vegetation cover sensitivity map of AP Vojvodina indicates the highest sensitivity in wind-exposed areas without any vegetation (Figure 7). Throughout March, in a large number of agricultural areas, the soil is unprotected, with a complete lack of vegetation (preparation of soil for sowing). Generally, higher wind velocity results in an increased sensitivity to wind erosion. The map of the climate factor sensitivity to wind erosion shows high sensitivity in the south-eastern and north-eastern parts of AP Vojvodina, as expected, due to the higher wind velocity in that part of the research area (Figure 5).

The results of wind erosion vulnerability for the whole research area were divided into categories, including high, medium, and low vulnerability (Table 1) [19]. The results for the area are presented in Figure 7. 
Table 1. Spatial distribution of sensitivity to wind erosion in AP Vojvodina.

\begin{tabular}{ccc}
\hline Fuzzy Value Interval & Sensitivity & Area (\%) \\
\hline $0.0-0.19$ & Low & 3.63 \\
\hline $0.2-0.39$ & Medium & 35.92 \\
\hline $0.4-0.9$ & High & 60.41 \\
\hline
\end{tabular}

After overlapping the individual maps of each contributing factor, based on CORINE Land Cover, an $8.5 \%$ share of the total research area was excluded as surfaces irrelevant for wind erosion. Areas with a sensitivity value higher than 0.4 are considered hazardous, and this sensitivity category occupied approximately $60.41 \%$ of the research area, while the medium sensitivity category accounted for around $36 \%$ of the research area. Similar results were reported by Letić et al. [43], who also showed that over $85 \%$ of the area in the AP Vojvodina was either disturbed or very disturbed (fragile) soils. In AP Vojvodina, more than $75 \%$ of the area is used for agriculture [44]. Furthermore, there is insufficient forest vegetation cover in the form of protective forests and protective forest belts (in AP Vojvodina the forest cover amounts to approximately $6 \%$ ). Particularly in March, agricultural areas are prepared for sowing and left without any vegetation. Given that vegetation plays an important role in the protection of soils, a large part of the agricultural area becomes very vulnerable. Similar results on the wind erosion of agricultural areas without vegetation in spring months were reported by Mezösi et al. [19]. When unfavorable climate (wind velocity) was combined with soil characteristics of the northern and southeastern parts, these two regions of the research area emerged as the most vulnerable to wind erosion (Figure 8). In the south-eastern area of AP Vojvodina, we found the most extensive climate conditions, with the highest mean wind velocity and number of days with stormy winds (with speeds of above $18.9 \mathrm{~m} \mathrm{~s}^{-1}$ ). The potential vulnerability to wind erosion in the northern area is due to slightly worse physical and chemical characteristics of the soil. In prior research on the vulnerability of the entire area of the AP Vojvodina, similar results were found by Velasević [45] and Savić [12], and the most severely affected areas were northern and southeastern parts of AP Vojvodina.

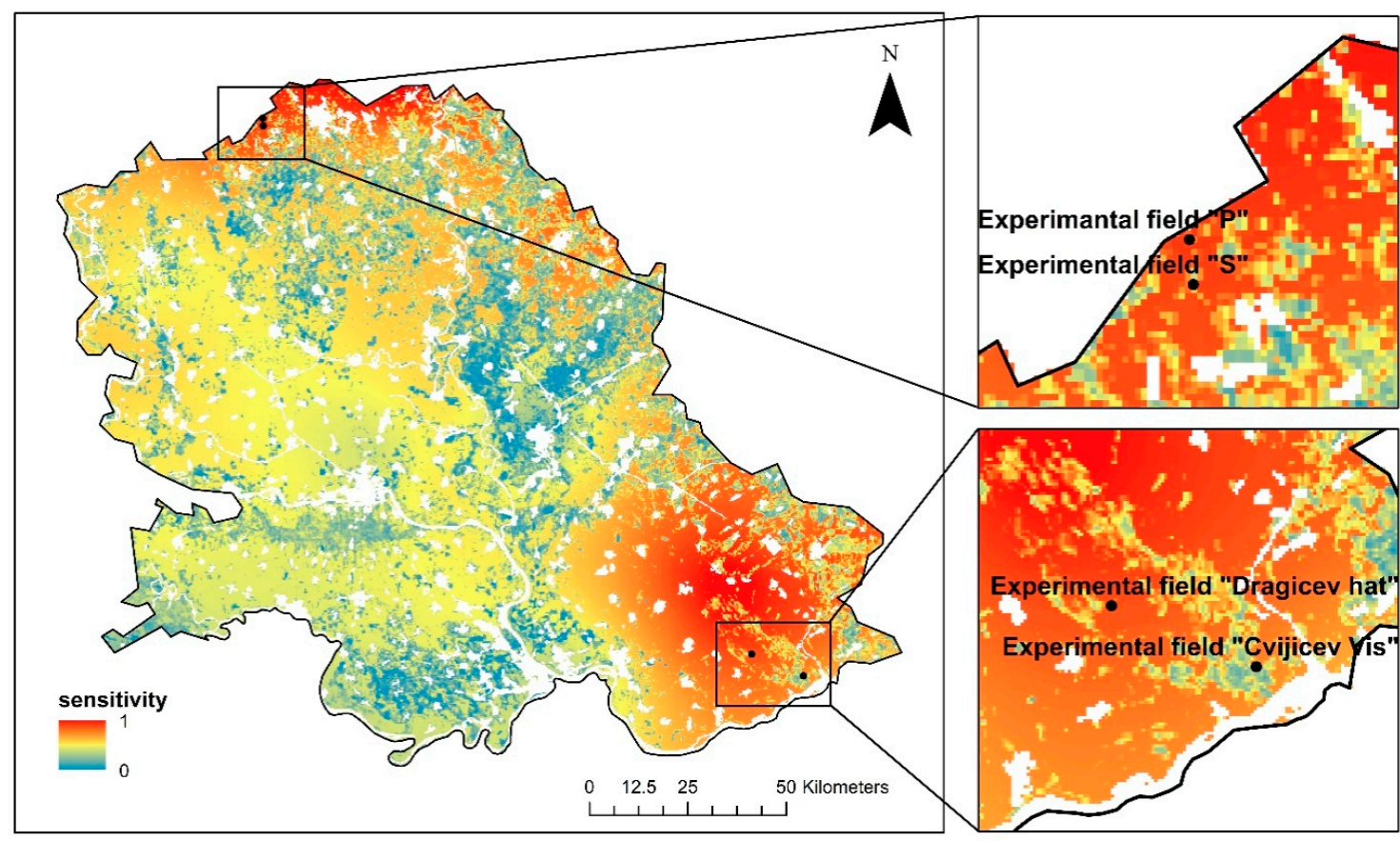

Figure 8. Wind erosion sensitivity at the regional level with sample plots.

The most vulnerable parts of the research area (northern and southeastern parts) contain two sandy areas—-the Deliblato and Horgoš sands [46]. Although they are not agricultural areas, a high 
probability of sand detachment in these places has negative impacts on agriculture [47]. In the past, ameliorative works (reforestation) were carried out in these very areas in order to protect the soil from wind erosion [48]. Studies on the intensity of wind erosion in the Republic of Serbia and AP Vojvodina were carried out (in sandy areas) in four sample plots and at two locations which were used for validation in this research. The first location was positioned in a highly vulnerable area in the north of the research area-the Deliblato sands, where Veloić [13] conducted research at two locations, Cvijićev vis and Dragićev hat. Veloić's [13] research involved quantification of the erosion process using mechanical sediment catchers. The amount of eolian sediment showed that the highest vulnerability occurs in February and March. The results also showed that in the Cvijicev vis site, the intensity of eolian erosion is four times higher than the intensity of eolian erosion in the Dragicev hat site. These results are in accordance with the obtained results presented on the sensitivity map (Figure 7). The higher soil loss at Cvijicev Vis has a direct correlation with the vegetation cover of the soil. This site, compared to the other one, is located in an area where the vegetation cover is significant. The second sample plot was located in the southeastern part of the research area-the Horgoš sands, where Velasević and Letić [20] measured the amount of eolian sediments in two sites (P and S). While site $S$ had good vegetation cover, site $P$ was located on barren land. Based on the results of this research, the highest losses in both sites were recorded in late winter and early spring (February and March). Greater losses were found in site P compared to site S, which had adequate protective vegetation (Figure 8). These results are also in line with the newly created sensitivity map for that area. The soil losses in both these sample plots confirm that several times more loss occurs in areas without protective vegetation.

\section{Conclusions}

This research investigated the relevant factors (soil, vegetation cover, and climate) with an impact on large scale wind erosion. The highest wind erosion risk was identified in the northern and southeastern parts of the research area, due to the presence of agricultural areas with no protective vegetation, which also experience frequent and strong winds. The results of this research show an extreme risk of wind erosion. Even though the southeastern and northern parts of the research area were found to be most seriously at risk, it must be noted that the entire research area is threatened by wind erosion. This model allows us to identify the zones that are the most vulnerable to wind erosion. However, its drawback is the lack of option to quantify erosion processes and determine the wind erosion rate of certain areas (in measurable units).

These findings are disturbing and should serve as the basis for planning agricultural policy. The focus should be on the implementation of suitable measures aimed at increasing the forest vegetation cover. This type of vegetation, in the form of protective forest belts, provides the most effective protection from wind erosion.

In order to obtain a more comprehensive understanding of areas sensitive to wind erosion, the aims of further research should include a forecast of climate that could affect such areas. In addition to that, the attention of researchers should be focused on other factors which can only be observed at the small-scale level, such as the impact of windbreaks and wind path length on the sensitivity of areas to eolian erosion.

Author Contributions: Conceptualization, A.B. and S.L.; Data curation, A.B.; Formal analysis, A.B.; Investigation, A.B.; Methodology, A.B.; Resources, S.L.; Supervision, S.L. and S.B.S.; Visualization, A.B.; Writing一original draft, A.B.; Writing-review and editing, S.L., S.B.S. and R.K.

Acknowledgments: This work was carried out as part of the project "Investigation of Climate Change and their Environmental Impact-Monitoring of Impact and Adaptation and Mitigation" (III43007 2011-2018) funded by the Ministry of Education and Science of the Republic of Serbia.

Conflicts of Interest: The authors declare no conflict of interest. 


\section{References}

1. Sterk, G.; Riksen, M.; Goossens, D. Dryland degradation by wind erosion and its control. Ann. Arid Zone 2001, 40, 351-367.

2. Buschiazzo, D.; Funk, R. Wind erosion of agricultural soils and the carbon cycle. In Science, Management and Policy for Multiple Benefits; Banwart, S.A., Noellemeyer, E., Milne, E., Eds.; Centre for Agriculture and Biosciences International: Wallingford, UK, 2015; pp. 161-168.

3. Santra, P.; Moharana, P.; Kumar, M.; Soni, M.L.; Pandey, C.B.; Chaudhari, S.K.; Sikka, A.K. Crop production and economic loss due to wind erosion in hot arid ecosystem of India. Aeolian Res. 2017, 28, 71-82. [CrossRef]

4. Skidmore, E. Air, Soil, and water quality as influenced by wind erosion and strategies for mitigation. In Proceedings of the AGROENVIRON 2000, 2nd International Symposium of New Technologies for Environmental Monitoring and Agro-Applications, Tekirdag, Turkey, 18-20 October 2000.

5. European Environmental Agency. The State of Soil in Europe; European Commission: Brussel, Belgium, 2010. [CrossRef]

6. Food and Agriculture Organization of United Nations (FAO). Country Report on the State of Plant Genetic Resources for Food and Agriculture, Country Report_Republic of Serbia; FAO: Roma, Italy, 2010.

7. Milošević, D.; Savić, S.; Stojanović, V.; Popov-Raljić, J. Effects of precipitation and temperatures on crop yield variability in Vojvodina (Serbia). Ital. J. Agrometeorol. 2015, 3, 35-44.

8. Vojvodinašume (Eng. VojvodnaForests)_Estimation of the Optimum Afforestation in Vojvodina. Available online: https://www.vojvodinasume.rs/en/sume/procena-optimalne-sumovitosti-u-vojvodini/ (accessed on 18 October 2019).

9. Vojvodina Development Agency. Available online: http://rav.org.rs/key-sectors/agribusiness/ (accessed on 18 October 2019).

10. Jevtić, L.J. Mogućnost Određivanja Srednje-Godišnjeg Intenziteta Eolske Erozije Putem Mernih Instrumenata. Ph.D. Thesis, Univesity of Belgrade, Belgrade, Serbia, 1970.

11. Letić, L.J. Research of Wind Erosion Intensity in the Region of Subotica-Horgoš Sands. Ph.D. Thesis, Univesity of Belgrade, Belgrade, Serbia, 1989.

12. Savić, R. Ugroženost Zemljišta Vojvodine Eolskom Erozijom. Ph.D. Thesis, Univesity of Belgrade, Belgrade, Serbia, 2000.

13. Veloić, M. Wind Erosion Quantification Process in Deliblato Sands. Ph.D. Thesis, University of Novi Sad, Novi Sad, Serbia, 2016.

14. Woodruff, N.P.; Siddoway, F.H. A Wind Erosion Equation; Soil Science Society of America: Madison, WI, USA, 1965.

15. Fryrear, D.W.; Saleh, A.; Bilbro, J.D.; Schomberg, H.M.; Stout, J.E.; Zobeck, T.M. Revised Wind Erosion Equation; Technical Bulletin No. 1; Southern Plain Area Cropping Systems Research Laboratory, USDA-ARS: College Station, TX, USA, 1998.

16. Mandakn, N.; Tsogtbaatar, J.; Dash, D.; Khudulmur, S. Spatial assessment of soil wind erosion using WEQ approach in Mongolia. J. Geogr. Sci. 2016, 26, 473-483. [CrossRef]

17. Guo, Z.; Zobech, T.M.; Zhang, K.; Li, F. Estimating potential wind erosion of agricultural lands in northern China using the Revised Wind Erosion Equation and geographic information systems. J. Soil Water Conserv. 2013, 68, 3-21. [CrossRef]

18. Mirmousavi, S.H. Regional modeling of wind erosion in the North West and South West of Iran. Eurasian Soil Sci. 2014, 49, 942-953. [CrossRef]

19. Mezösi, G.; Blanka, V.; Bata, T.; Kovacs, F.; Meyer, B. Estimation of regional differences in wind erosion sensitivity in Hungary. Nat. Hazards Earth Syst. Sci. 2015, 15, 97-107. [CrossRef]

20. Velasević, V.; Letić, L.J. Research of wind erosion intensity in the region of Subotica-Horgos sand. In Proceedings of the IUFRO Technical Session on Geomorphic Hazards in Managed Forests, Montreal, QC, Canada, 5-11 August 1991.

21. Lalić, B.; Mihailović, D.; Podraščanin, Z. Future state of climate in Vojvodina and expected effects on crop production. Field Veg. Crop Res. 2011, 48, 403-418. [CrossRef]

22. Wind Atlas Balkan (WAB). Available online: https://balkan.wind-index.com/ (accessed on 5 October 2019).

23. Republic Hydrometeorological Service of Serbia. (RHMOS). Available online: http://www.hidmet.gov.rs/ latin/meteorologija/klimatologija_godisnjaci.php (accessed on 5 October 2019). 
24. Živković, B.; Nejgebauer, V.; Tanasijević, Đ.; Miljković, N.; Stojković, L.; Drezgić, P. Soils of Vovjodina; Institute for Agricultural Research: Novi Sad, Serbia, 1972.

25. Copernicus Global Land Service (CGLS). NDVI. Available online: https://land.copernicus.eu/global/products/ ndvi (accessed on 4 November 2019).

26. Copernicus Global Land Service (CGLS). CORINE LAND COVER 2018. Available online: https://land. copernicus.eu/pan-european/corine-land-cover/clc2018 (accessed on 5 October 2019).

27. Chepil, W.S. Relation of wind erosion to the dry aggregate structure of a soil. J. Sci. Food Agric. 1941, 21, 488-507.

28. Borrelli, P.; Ballabio, C.; Panagos, P.; Montanarella, L. Wind erosion susceptibility of European soils. Geoderma 2014, 232-234, 471-478. [CrossRef]

29. Borrelli, P.; Panagos, P.; Ballabio, C.; Lugato, E.; Weynants, M.; Montanarella, L. Towards a pan-Europan assessment of land susceptibility to wind erosion. Land Degrad. Dev. 2014, 27, 1093-1105. [CrossRef]

30. Borrelli, P.; Panagos, P.; Montanarella, L. New insights into the geography and modelling of wind erosion in the European agricultural land. Application of a spatially explicit indicator of land susceptibility to wind erosion. Sustainability 2015, 7, 8823-8836. [CrossRef]

31. Fryrear, D.W.; Bilbro, J.D.; Saleh, A.; Schomberg, H.M.; Stout, J.E.; Zobeck, T.M. RWEQ: Improved wind erosion technology. J. Soil Water Conserv. 2000, 55, 183-189.

32. Saadoud, D.; Hassani, M.; Peinado, F.J.M.; Guettouche, M.S. Application of fuzzy logic approach for wind erosion hazard mapping in Laghouat region (Algeria) using remote sensing and GIS. Aeolian Res. 2018, 32, 24-34. [CrossRef]

33. Mezösi, G.; Blanka, V.; Bata, T.; Ladanyi, Z.; Kemeny, G.; Meyer, B. Assessment of future scenarios for wind erosion sensitivity changes based on ALADIN and REMO regional climate model simulation data. Open Geosci. 2016, 8, 465-477. [CrossRef]

34. Kadović, R.; Bohajar, Y.; Perović, V.; Simić, S.B.; Todosijević, M.; Tošić, S.; Anđelić, M.; Mlađan, D.; Dovezenski, U. Land sensitivity analysis of degradation using MEDALUS model: Case study of Deliblato Sands, Serbia. Arch. Environ. Prot. 2016, 42, 114-124. [CrossRef]

35. Savić, R.; Letić, L.J.; Benka, P.; Ondrašek, G.; Nikolić, V. Spatial and temporal distribution of potential vulnerability to wind erosion processes in Vojvodina. Agroznanje Agro Knowl. J. 2012, 13, 191-198. [CrossRef]

36. Svoboda, M.; Fuchs, B.A. Handbook of drought indicators and indices. In Integrated Drought Management Programme (IDMP), Integrated Drought Management Tools and Guidelines Series 2; World Meteorological Organization (WMO) and Global Water Partnership (GWP): Geneva, Switzerland, 2016.

37. Grant, P.; Nickling, W. Direct field measurement of wind drag on vegetation for application to windbreak design and modelling. Land Degrad. Dev. 1998, 9, 57-66. [CrossRef]

38. Zadeh, L.A. Fuzzy sets. Inf. Control. 1965, 8, 338-353. [CrossRef]

39. Song, Y.; Liu, L.; Yan, P.; Cao, T. A review of soil erodibility in water and wind erosion research. J. Geogr. Sci. 2005, 15, 167-176. [CrossRef]

40. Słowińska-Jurkiewicz, A.; Bryk, M.; Medvedev, V.V. Long-term organic fertilization effect on chernozem structure. Int. Agrophys. 2013, 27, 81-87. [CrossRef]

41. Blanco-Canqui, H.; Lal, R. Wind erosion. In Principles of Soil Conservation and Management; Springer: Dordrecht, The Netherlands, 2010; pp. 55-80. [CrossRef]

42. Youssef, F.; Visser, S.M.; Karssenberg, D.; Erpul, G.; Cornelis, W.M.; Gabriels, D.; Poortinga, A. The effect of vegetation patterns on wind-blown mass transport at the regional scale: A wind-tunnel experiment. Geomorphology 2012, 158-159, 178-188. [CrossRef]

43. Letić, L.J.; Štefkić, D.; Blesić, P. Eolska erozija na području SAP Vojvodine. Zemljište biljka 1984, 33, 121-128.

44. Banski, J.; Bednared-Szceepanska, M.; Czapiewski, K.; Mazur, M. Perspectives for Agriculture of Vojvodina in the Light of Scenarios and Models Elaborated in the Framework of the Research Project; Institute of Geography and Spatial Organization PAS: Warsaw, Poland, 2010.

45. Velašević, V. Prilog Proučavanju Optimalnih Konstrukcija Šumskih Snegobranih Pojaseva. Master's Thesis, Univesity of Belgrade, Belgrade, Serbia, 1967.

46. Gavrilov, M.B.; Marković, S.B.; Schaetzl, R.J.; Tošić, I.; Zeeden, C.; Obreht, I.; Lehmkuhl, F. Prevailing surface winds in Northern Serbia in the recent and past time periods; modern-and past dust deposition. Aeolian Res. 2018, 31, 117-129. [CrossRef] 
47. Mezösi, G.; Szatmári, J. Assessment of wind erosion risk on the agricultural area of the southern part of Hungary. J. Hazard. Mater. 1998, 61, 139-153. [CrossRef]

48. Šijačić-Nikolić, M.; Vilotić, D.; Radović, M.; Stanković, D. Application of super-absorbant polymers in forestation of degraded terrains. Topola 2008, 181-182, 21-29. 